\title{
HEMATOLOGICAL AND HISTOLOGICAL RESPONSE TO THE DIET CONTAINING AFLATOXIN B AND ZEOLITE IN BROILERS OF DOMESTIC FOWL
}

\section{Z. SOVA, ${ }^{1}$ Hana POHUNKOVA' Hana REISNEROVA, ${ }^{1}$ Alžběta SLAMOVÁ,1 K. HAISL:}

1) Department of Physiology and Zoology, University of Agriculture, 16521 Praha 6 - Suchdol; .

2) Medical Faculty of Hygiene, Charles University, 10042 Praha 10, Srobárova 48;

3) Central State Veterinary Institute, 16503 Praha 6

Received October 16, 1989

\begin{abstract}
Z. Sova, Hana Pohunková, Hana Reisnerová, Alžběta Slámová, K. Hais 1: Hematological and Histological Response to the Diet Containing Aflatoxin $B_{1}$ and Zeolite in Broilers of Domestic Fowl. Acta vet. Brno, 60, 1991: 31-40:

The experiment was performed on twenty nine healthy broilers from the school farm. The birds were divided into four groups: control group I, group II fed with diet to which $5 \%$ of zeolite $\mathrm{kg}^{-1}$ was added, group III fed with diet containing $5 \%$ of zeolite and $2.5 \mathrm{mg}$ of aflatoxin $\mathrm{B}_{1} . \mathrm{kg}^{1}$, and group IV fed with diet with only $2.5 \mathrm{mg}$ of aflatoxin $B_{1} . \mathrm{kg}^{-1}$. Three or four broilers from each group were killed after five and twelve days of the experiment. Broilers in the group IV showed both serious heterophilia and lymphopenia. In the group III this shift was not so evident. In both groups III and IV features of acute alteration of liver parenchyma charracterized by the activation of Kupffer's cells and by dilatation of bile canaliculi and cholestasis were found. Similar focal changes were revealed also in liver tissue of broilers in the group II after twelve days of experiment. Results obtained suggest not only that the addition of $5 \%$ of zeolite $\mathrm{kg}^{-1}$ to the food does not protect liver tissue against toxic effects of aflatoxin $B_{1}$ but also that zeolite itself is not harmless for broilers.
\end{abstract}

\section{Broilers, zeolite, aflatoxin $B_{1}$, hematology, liver histology}

Aflatoxins, with their hepatotoxic and nephrotoxic effects belong to the most toxic mycotoxins(Mollenhauer et al. 1989); they may affect the hemopoietic organs, the nervous system or reproductive organs (Hafez et al. 1979; Clarke et al. 1986; Sova et al. 1989). Aflatoxins specifically affect the DNA of hepatic cells what is taken for critical target for initiation of carcinogenesis (Chu 1977; Stark 1980). Aflatoxins may affect also the immunological processes and reduce resistance of the organism particularly against infection (Edds 1983). Aflatoxin $B_{1}\left(A F B_{1}\right)$ is a mycotoxin with really worldwide distribution and that has made it an unavoidable food contaminant. Great effort has been paid to find an effective way for decontamination of the feed-stuffs. Economically acceptable possibilities of decontamination of food-stuffs infected with mycotoxins have been investigated under conditions of agricultural large-scale production. One of the substances potentially perspective for this purpose is believed to be zeolite. Zeolites are hydrated crystalline aluminosilicates of cations of alkaline soils obtained from natural sources (clinoptilotite) or prepared artificially (permutites). They are usually used for adsorption of gases, in civil engineering, medicine, pharmacy and in water management. In agriculture, zeolites have been used to lesser extent mostly for the improvement of zoohygienic conditions (removal of odours), as bedding for animals, and for the prevention of diarrhoea in young animals. The use of zeolites as feed additives for various animals (incorporated in feed mixtures) is being tested. Bartko and Vrzgula (1981) used zeolite from the locality Nižný Hrabovec for preparation of feed mixtures for pigs, cattle and broilers and they claimed to have obtained good results both in performance and feed conversion. On the contrary Koči (1984) stated that the addition of $4 \%$ of zeolite to the feed mixture for broilers caused a significant depression of growth and impaired utilization of the feed; but the addition of 2 to $3 \%$ of zeolite to the feed mixture improved fattening. Sova et al. (1988). 
studied the effect of the addition of $2 \%$ of zeolite to feed mixtures for broilers containing aflatoxins on metabolic liver tests. They proved that 10 days of feeding the mixture containing $97.5 \mu \mathrm{g}$ of $\mathrm{AFB}_{1}$ and $98.8 \mu \mathrm{g}$ of $\mathrm{AFG}_{1}$ with $2 \%$ of zeolite $\mathrm{kg}^{-1}$ did not affect the values of the metabolic tests. Mižik et al. (1989) studied the decontamination effect of zeolite in rats and found, that feeding a diet with a $2.5-5.0-10.0 \%$ of zeolite caused increased excretion of ${ }^{184} \mathrm{Cs}$ via faeces and decreased deposition of this radionuclide in the tissue. Dvořák (1989) studied the adsorption capacity of zeolite and bentonite with regard to aflatoxin in fluid media in vitro. According to his findings average retention of aflatoxin in adsorbents was $66 \%$ in bentonite and $60 \%$ in zeolite of the original content in the media respectively.

\section{Materials and Methods}

The experimental animals (Hybro broilers, 42 days old) were obtained from the school farm of the University of Agriculture in Prague as well as commonly used feed mixtures. These clinically healthy broilers from the farm were chosen intentionally in order to simulate as well as possible conditions of use of zeolite in practice on farms. During the one-week adaptation period and also during the experiment, the animals were fed feed $n_{.}$ixtures BR1 and BR2. Absence of AFB in these feed mixtures was checked by means of RIA methods. Ani r als were provided with water ad libitum. Tab. 1 shows the initial arrangement of animals in the experimental groups (I-IV).

Zeolite originated from Nižný Hrabovec and its composition was as follows: $65-70 \% \mathrm{SiO}_{2}$, $11.8-12.8 \% \mathrm{AlO}_{2}, 1.3-3.9 \% \mathrm{CaO}, 0.9-2.6 \% \mathrm{Fe}_{2} \mathrm{O}_{3}$, the content of the other oxides was lower than $1 \%$, the content of $\mathrm{Pb}, \mathrm{Cd}$ and $\mathrm{As}$ was lower than $1 \mathrm{mg} \cdot \mathrm{kg}^{1}$, and the content of clinoptilotite in it was $42-61 \%$.

Table 1

Division of broilers into groups

\begin{tabular}{|c|c|c|c|c|}
\hline \multirow{2}{*}{ Group } & \multirow{2}{*}{ Feed mixture and addition } & \multirow{2}{*}{$\mathbf{n}$} & \multicolumn{2}{|c|}{$\begin{array}{l}\text { Numerical indication of the } \\
\text { killed broilers }\end{array}$} \\
\hline & & & after 5 days & after 12 days \\
\hline $\mathbf{I}$ & control & 6 & $1,2,3$ & $15,16,17$ \\
\hline II & $\begin{array}{l}\mathrm{BR}_{1}+\mathrm{BR}_{2} \text { mixtures } \\
\mathrm{BR}_{1}+\mathrm{BR}_{2} \text { mixtures }\end{array}$ & 7 & $4,5,6$ & $18,19,20,21$ \\
\hline III & $\begin{array}{l}+3 \% \text { of zeolite } \\
\mathrm{BR}_{1}+\mathrm{BR}_{\mathrm{y}} \text { mixtures }\end{array}$ & 8 & $7,8,9,10$ & $22,23,24,25$ \\
\hline IV & $\begin{array}{l}\mathrm{BR}_{1}+\mathrm{BR}_{2} \text { mixtures } \\
+2.5 \mathrm{mg} \mathrm{AFB} \\
\mathrm{kg}^{-1}\end{array}$ & 8 & $11,12,13,14$ & $26,27,28,29$ \\
\hline
\end{tabular}

Aflatoxin $\mathrm{B}_{1}$ was isolated from the highly toxicogenic strain of Aspergillus flavus at the Institute of Hygiene and Epidemiology in Brno.

Broilers in four groups (each of 6 to 8 animals) were fed 5-12 days with diet, which in group I did not contain any additive. In the group II, $5 \%$ of zeolite. $\mathrm{kg}^{-1}$ was added to the feed mixture; $5 \%$ of zeolite and $2.5 \%$ of $A F B_{1} . \mathrm{kg}^{-1}$ of feed mixture was added for group III, and for group IV only $2.5 \mathrm{mg}$ of $\mathrm{AFB}_{1} . \mathrm{kg}^{-1}$.

Blood smears were stained according to Giemsa - Romanowsky. The value of hematocrit (Ht) was determined by means of microhematocrite method and that of hemoglobin (Hb) by hemoglobin-cyanide method. The liver tissue was fixed in $4 \%$ formaldehyde and processed for routine histology. Sections were stained with hematoxylin and eosin. In addition to that periodic acid Schiff method for glycogen and Lillies' technic for $\mathrm{Fe}^{3+}$ and $\mathrm{Fe}^{2}+$ bearing pigments were used.

Primary magnification of the pictures is $\times 40$.

\section{Results and Discussion}

The results of hematological investigation are included in Table 2 . In the control group I the values of $\mathrm{Hb}, \mathrm{Ht}$ and leucograms obtained during sampling throughout the experiment ranged within basic physiological values, and were in accordance with results of Mohiuddin et al. (1986) and Pegram et al. (1986). 
Table 2

Selected values of hematological observations in broilers in the course of the experiment

\begin{tabular}{|c|c|c|c|c|c|c|c|c|}
\hline \multirow{2}{*}{$\begin{array}{l}\text { Indicator } \\
- \\
\mathrm{Hk}\left(1.1^{-1}\right) \\
\mathrm{Hb} \\
\left(\mathrm{mmol} \mathrm{.1^{-1 } )}\right.\end{array}$} & \multicolumn{2}{|c|}{$\begin{array}{c}\text { Group } I \\
5 \text { days } \quad 12 \text { days } \\
\text { control }\end{array}$} & \multicolumn{2}{|c|}{$\begin{array}{l}\text { Group II } \\
\text { er } \quad \text { after } \\
\text { ys } \quad 12 \text { days } \\
\% \text { of zeolite }\end{array}$} & \multicolumn{2}{|c|}{$\begin{array}{c}\text { Group III } \\
\text { after after } \\
5 \text { days } 12 \text { days } \\
5 \% \text { of zeolite }+ \\
2.5 \mathrm{mg} \mathrm{AFB}_{1} \cdot \mathrm{kg}^{-1}\end{array}$} & \multicolumn{2}{|c|}{ 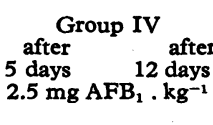 } \\
\hline & $\begin{array}{r}0.37 \\
\pm 0.01 \\
6.07 \\
\pm 1.27\end{array}$ & $\begin{array}{c}0.33 \\
\pm 0.03 \\
5.3 \\
\pm 0.26\end{array}$ & $\begin{array}{r}0.35 \\
\pm 0.03 \\
6.39 \\
\pm 0.38\end{array}$ & $\begin{array}{l}0.33 \\
\pm 0.01 \\
5.5 \\
\pm 0.46\end{array}$ & $\begin{array}{r}0.32 \\
\pm 0.02 \\
7 \\
\pm 1.06\end{array}$ & $\begin{array}{r}0.34 \\
\pm 0.03 \\
5.33 \\
\pm 0.36\end{array}$ & $\begin{array}{r}0.34 \\
\pm 0.07 \\
6.15 \\
\pm 0.41\end{array}$ & $\begin{array}{r}0.33 \\
+0.03 \\
5.85 \\
\pm 0.17\end{array}$ \\
\hline \multicolumn{9}{|c|}{ leukogram } \\
\hline $\begin{array}{l}\text { He } \\
\text { Ly } \\
\text { Eo } \\
\text { Ba } \\
\text { Mo }\end{array}$ & $\begin{array}{r}32.3 \\
\pm 1.2 \\
59.7 \\
\pm 2 \\
2.6 \\
\pm 0.5 \\
1 \\
\pm 0.8 \\
4.7 \\
\pm 0.5\end{array}$ & $\begin{array}{c}32.3 \\
\pm 2 \\
60.3 \\
\pm 2.5 \\
2.6 \\
\pm 0.5 \\
0.7 \\
\pm 0.5 \\
4 \\
\pm 0\end{array}$ & $\begin{array}{r}30.3 \\
\pm 0.5 \\
58 \\
\pm 1.4 \\
3.7 \\
\pm 0.5 \\
1.7 \\
\pm 0.9 \\
6.3 \\
\pm 0.5\end{array}$ & $\begin{array}{r}32.5 \\
\pm 2.2 \\
57 \\
\pm 0.7 \\
4.7 \\
\pm 0.8 \\
0.7 \\
\pm 0.8 \\
5 \\
\pm 0.7\end{array}$ & $\begin{array}{c}58.3 \\
\pm 1.9 \\
34.8 \\
\pm 1.6 \\
5 \\
\pm 0.7 \\
0 \\
2 \\
\pm 1\end{array}$ & $\begin{array}{c}61.5 \\
\pm 1.6 \\
30 \\
\pm 1.2 \\
7 \\
\pm 2 \\
0.25 \\
\pm 0.4 \\
1.3 \\
\pm 0.4\end{array}$ & $\begin{array}{c}62 \\
\pm 0 \\
29 \\
\pm 1 \\
6.8 \\
\pm 0.4 \\
0.5 \\
\pm 0.5 \\
1.8 \\
\pm 0.4\end{array}$ & $\begin{array}{c}65 \\
\pm 0.7 \\
27.5 \\
\pm 0.5 \\
5.3 \\
\pm 1.1 \\
0.25 \\
\pm 0.4 \\
1.8 \\
\pm 0.8\end{array}$ \\
\hline
\end{tabular}

Similar findings were obtained in group II, and they virtually did not differ from the results gained in group I. Thus we concluded, that the addition of $5 \%$ zeolite to the diet for 12 days did not affect the values of $\mathrm{Hb}, \mathrm{Ht}$ and leucogram. But also only minute differences in the values of $\mathrm{Hb}$ and $\mathrm{Ht}$ were found in the group III. On the contrary the values of leucocyte count in this group differed largely. Both in group III and IV heterofilia was increased even doubled compared with groups I and II. In between the 5th and 12th day a increase of heterofilia continued. This effect was in accordance with the contents of $2.5 \mathrm{mg}$ of $\mathrm{AFB}_{1} \cdot \mathrm{kg}^{-1}$ in the diet. Similar results obtained Campbell et al. (1982) and Jeffers et al. (1986) in experiments in poultry, and Sova et al. (1988) in hamsters. Increase of heterophils in groups III and IV was accompanied by severe lymphocytopenia (to about $50 \%$ of the initial values) with further decrease of lymphocytes in between the 5th and 12th days of experiment. Heterophilia and lymphocytopenia were worse in group IV than in group III. This difference seems to support the idea of favourable effect of zeolite used as an additive, too. However, further comparisons of values of leucograms showed that counts of eosinophiles were also in group III nad IV roughly doubled and the number of monocytes was decreased. Eosinophilia occurs generally in parasitic infestations and in allergic reactions. In this case it might be a result of an allergic reaction to the presence of mycotoxin. Lymphocytopenia is characteristic of many antibody-deficiency syndromes. Increase in the number of heterophils might indicate a tendency of the organism to compensate for the decrease of its resistance.

Histopathology of liver: Livers of broilers of group I showed some minute, predominantly monocellular foci of disintegrating cells. In the vicinity of these foci (mostly in the central regions of the lobuli) dilated bile canaliculi and hepatocytes with vacuolated cytoplasm and bile pigment were found. The bile ducts did not manifest greater change but non-purulent infiltrates in connective tissue in their vicinity were found. The blood capillaries were only here and there 


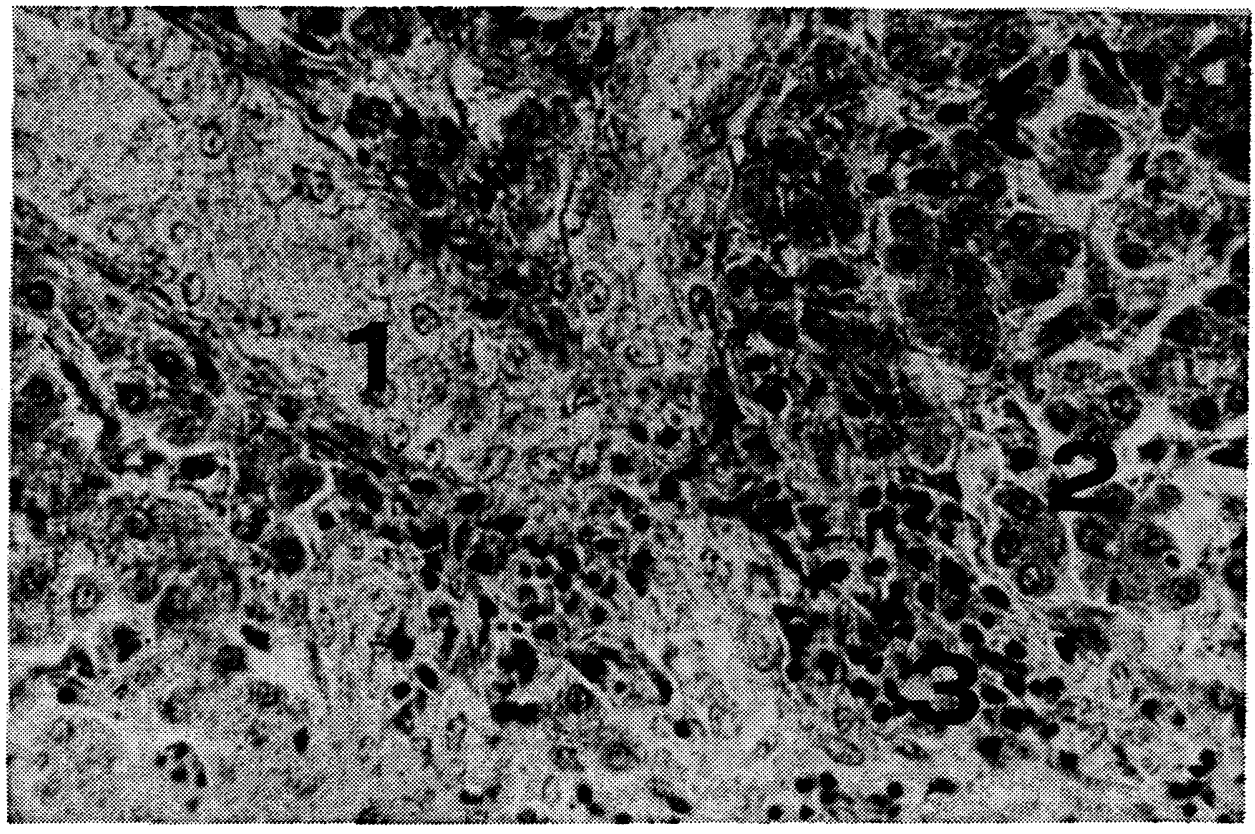

Fig. 1 (Group II - an addition of $5 \%$ of zeolite only) after 5 days. The surrounding of liver bile duct: 1 - edematous bile duct; 2 - dilated sinusoids; 3 - minute infiltrates

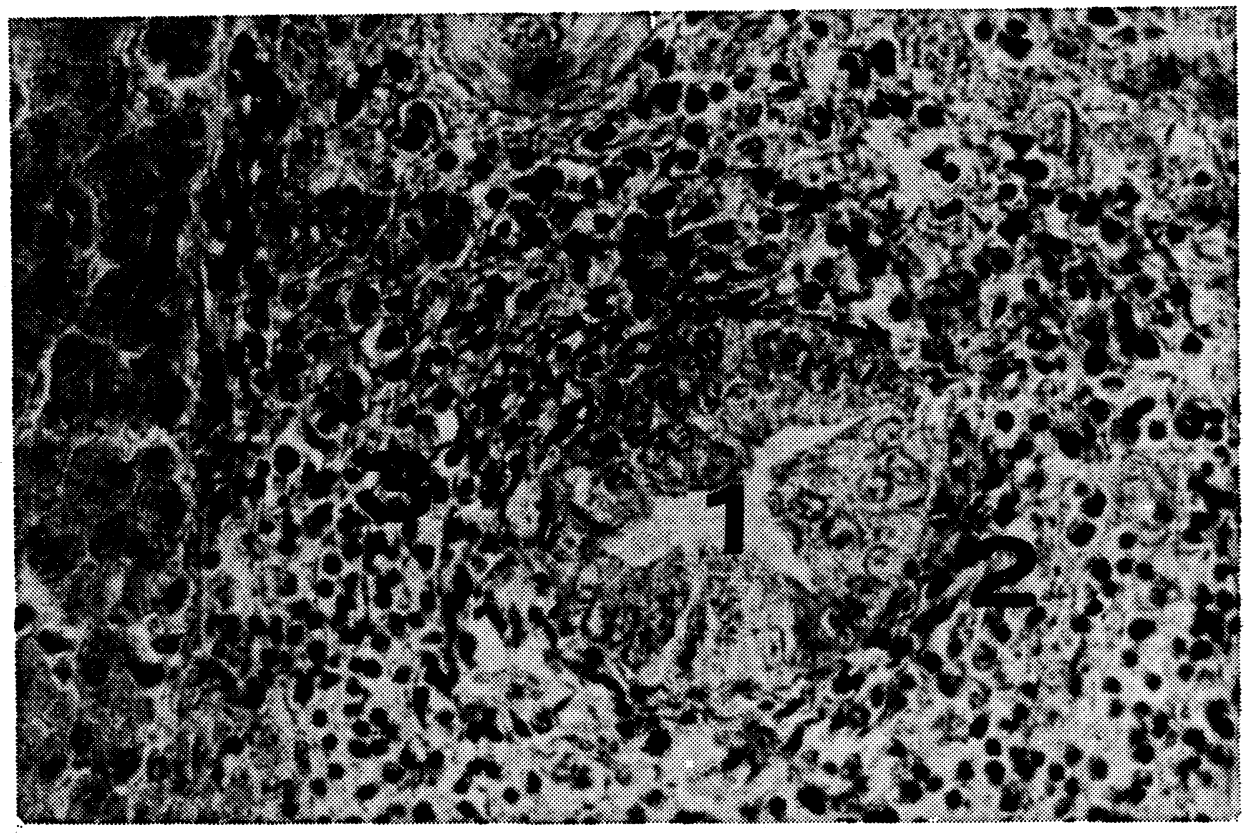

Fig. 2 (Group II - an addition of $5 \%$ of zeolite only) after 12 days. Portobiliary space of liver with large bile duct: 1 - bile duct; 2 - peribiliary infiltrate non-inflammatory: 3 - activated stellate (Kupffer's) cells 


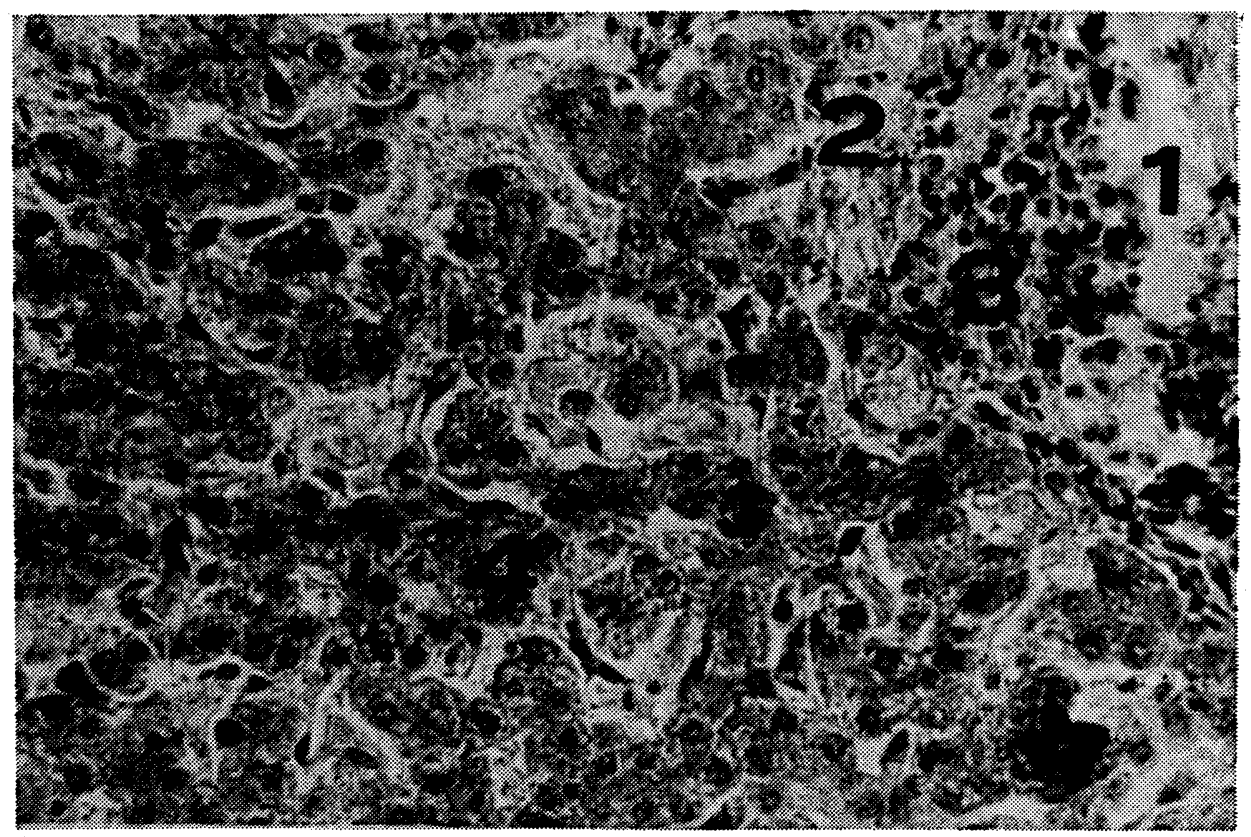

Fig. 3 (Group III - an addition of $5 \%$ of zeolite and $2.5 \mathrm{mg} \mathrm{AFB}_{1} \cdot \mathrm{kg}^{-1}$ of the feed ratio after 5 days. Portobiliary space of liver and surroundings: 1 - bile duct; 2 - vacuolization of cytoplasm of hepatocytes; 3 - round cellular infiltrate in the interstitium; 4 - diffused granular dystrophia of hepatocytes

slightly dilated. These findings bear evidence of previous subclinical irritation of the liver.

Group II - Fig. 1 (after 5 days of experiment). Among the majority of the hepatic cells with finely granular cytoplasm, perinuclear clear areas, and pigment in the cytoplasm, dispersed foci of decaying cells were observed. The bile canaliculi were unchanged. The blood capillaries were slightly dilated and contained variable amount of eosinophils. The epithelium of the bile ducts was slightly oedematous, otherwise unchanged. In the peribiliary connective tissue a non-purulent infiltration was found. Group II - Fig. 2 (after 12 days of experiment): Unicellular necrosis of the hepatic cells were observed. The cytoplasm of hepatocytes was distinctly granular and in some of them bile pigment was present. In the vicinity of damaged cells bile canaliculi were dilated. Oedema of the epithelium of bile ducts was also observed. Sporadic eosinophils were found in widened blood capillaries. The peribiliary infiltrates were not inflammatory.

Group III - Fig. 3 (after five days of experiment): Focal necrosis of the hepatic cells as well as the cells with extensive clear areas in their cytoplasm and cells with pigment were also characteristic for liver of broilers fed diet with zeolite and $\mathrm{AFB}_{1}$. The periphery of the hepatic lobules was in some places somewhat better preserved. Epithelium of the bile ducts was damaged unevenly. Some bile ducts were virtually unchanged. The peribiliary infiltrates contained here and there also eosinophilic granulocytes. Eosinophils were frequently found also in blood capillaries. Group III - Fig. 4 (after 12 days of experiment). All 


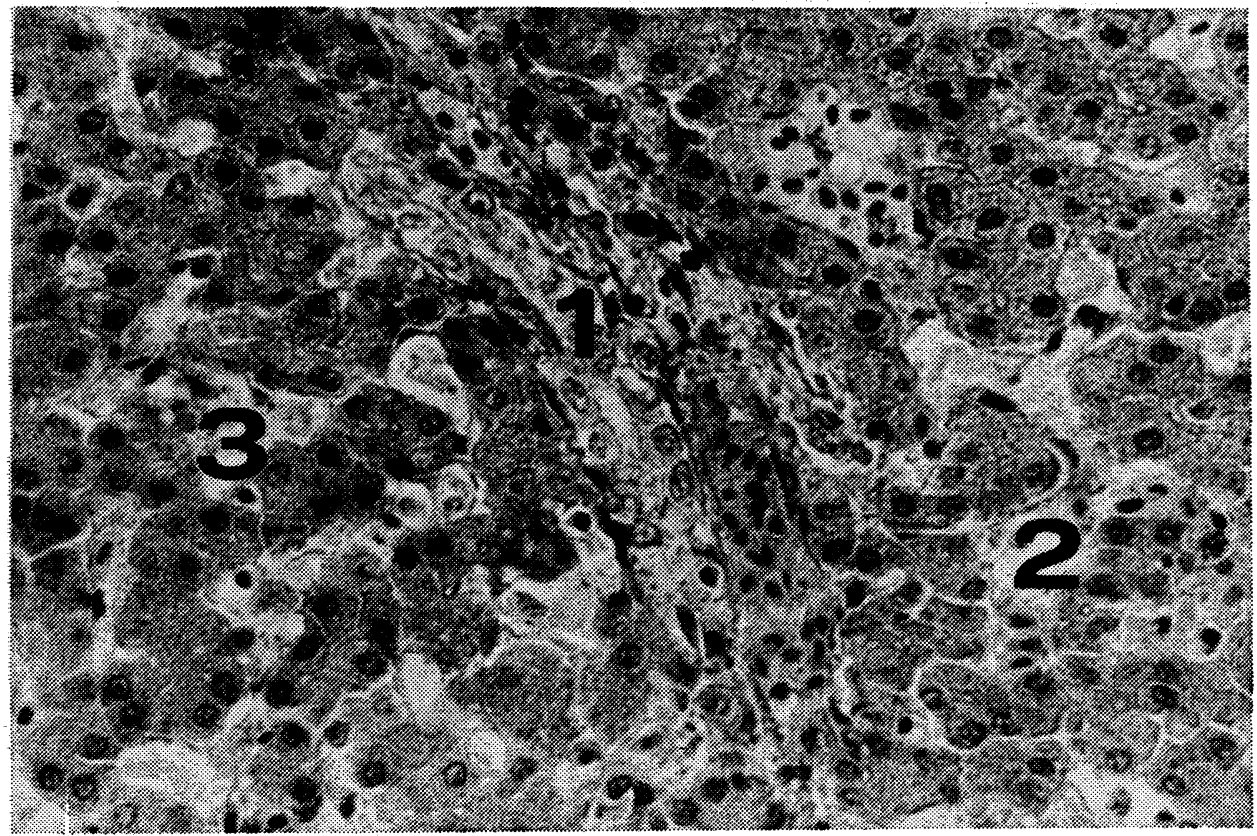

Fig. 4 (Group III - an addition of $5 \%$ of zeolite and $2.5 \mathrm{mg} \mathrm{AFB} \cdot \mathrm{kg}^{-1}$ of the feed ration) after 12 days. The surrounding of hepatic bile duct.

1 - Bile duct; 2 - dilated sinusoids; 3 - monocellular necroses

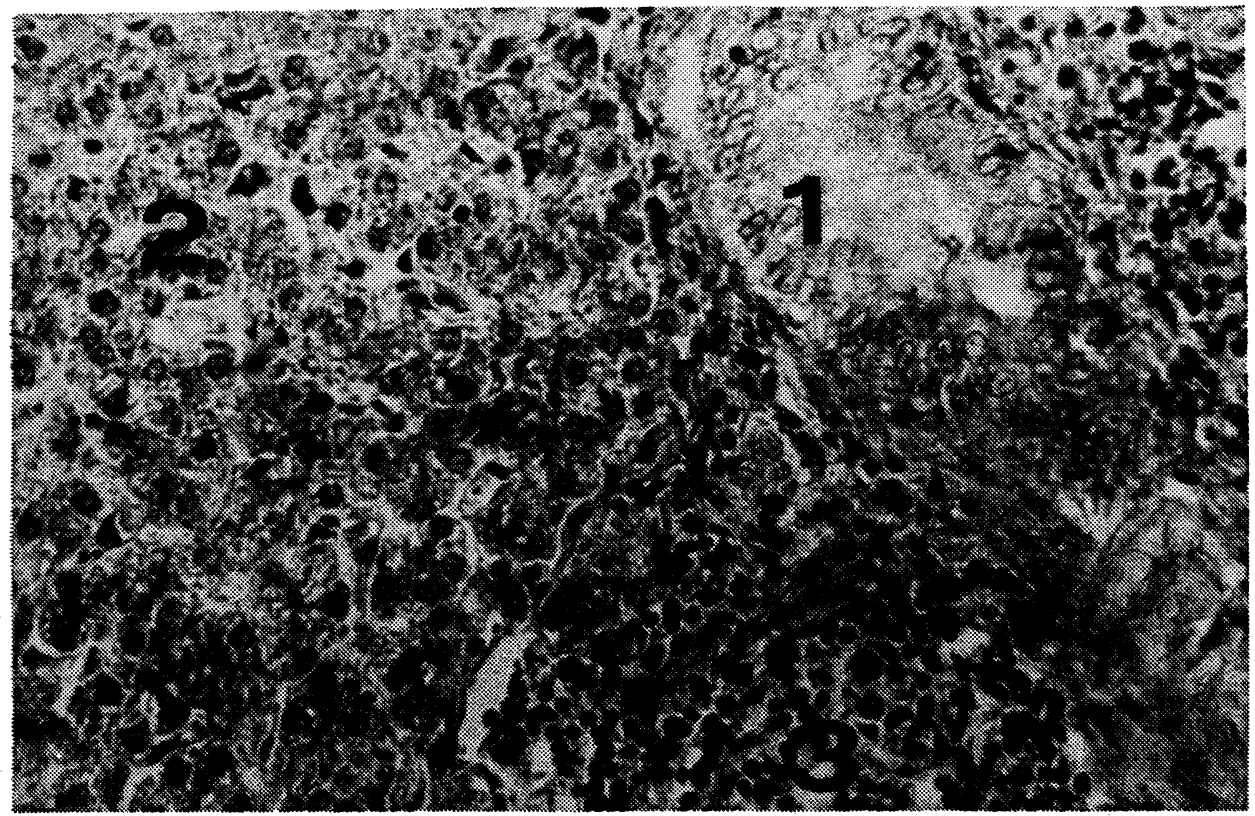

Fig. 5 (Group IV $-2.5 \mathrm{mg} \mathrm{AFB}_{1} \cdot \mathrm{kg}^{-1}$ of the feed ration) after 5 days. Serious damage of hepatic cells around bile duct: 1 - bile duct; 2 - disintegration of hepatic cells; 3 - round cellular infiltrate 


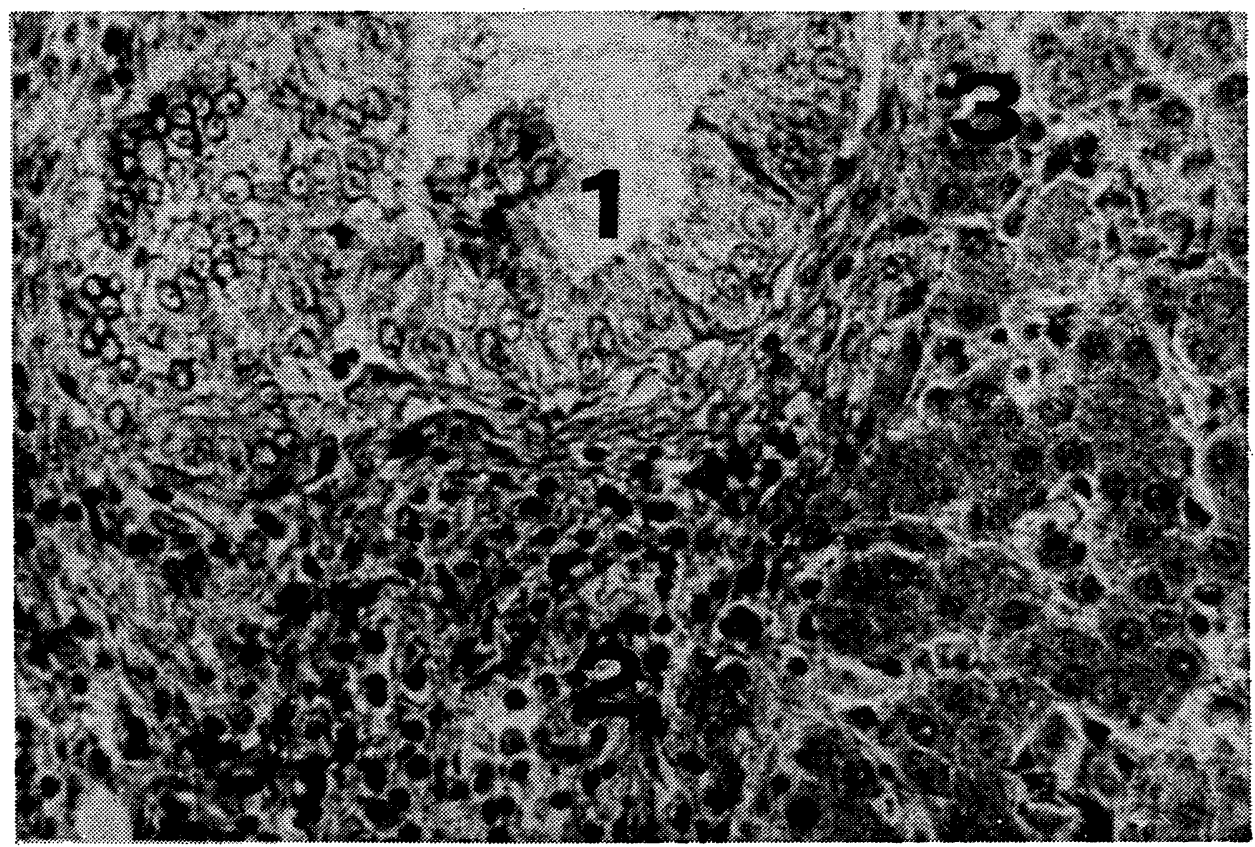

Fig. 6 (Group IV $-2.5 \mathrm{mg} \mathrm{AFB}_{1} \cdot \mathrm{kg}^{-1}$ of feed ration) after 12 days. Portobiliary space of liver. 1 - bile duct; 2 - numerous foci of peribiliary infiltrate; 3 - monocellular necrosis of hepatocytes.

hepatocytes were severely damaged. Monocellular and focal necrosis were frequently observed, as well as great differences in the stainability of the hepatic cells. In the majority of hepatocytes also bile pigment occurred. Sporadic mitoses were found in the vicinity of focal lesions. The bile canaliculi were mostly widened. In the smaller bile ducts an oedema of the epithelium, even closures of lumen were observed. In the hepatic sinusoids numerous eosinophils were seen. Lymphohistiocytic infiltrate was found both in the peribiliary connective tissue and in the lobular tissue.

Group IV - Fig. 5 (after 5 days of experiment). The hepatic cells were damaged especially on the periphery of the lobules. In the granular cytoplasm of hepatocytes extensive clear areas appearde. The bile canaliculi were widened. Eosinophils were frequently seen in blood capillaries. Peribiliary infiltrates were non-purulent. Group IV - Fig. 6 (after 12 days of experiment). Monocellular and focal necroses of hepatocytes were frequent. The appearance of the cytoplasm of hepatocytes was granular. On the periphery of the lobules sporadic mitoses and binucleic cells occurred. Eosinophilic granulocytes were often found in blood capillaries. Increased activation of Kupffer's cells was seen. The bile canaliculi were dilated, but the oedema of the epithelium of the bile ducts was uneven. Frequent foci of non-purulent peribiliary infiltrates were observed as well as minute foci of infiltrates in the parenchyma.

Similar changes in liver tissue after administration of various doses of aflatoxin $B_{1}$ described Sova et al. (1988) and Dafalla et al. (1987). Besides of our previous study (Sova et al. 1988) dealing with effect of an adaition of $2 \%$ of zeolite to 
the diet with mycotoxin the parallel effect of zeolite and mycotoxins on the structure of liver tissue has not been studied. Because the low concentration of zeolite in our previous study was found to be not sufficient for effective protection of liver in the actual experiment a higher concentration ( $5 \%$ ) of zeolite was used, but again with no effect.

Accumulation or depletion of glycogen was not observed by means of periodic acid Schiff method. Lillies' technic for Fe-bearing pigments brought positive results only in Kupffer cells in group III and IV.

Our results indicate that although the hematological values found in group II were within the physiological range, the histopathological findings in livers of broilers in group II and III brought doubts about protective effect of zeolite. And the results obtained in group II also suggest that zeolite itself in $5 \%$ concentration added to the diet of broilers is not harmless.

\section{Hematologická a morfologická odezva u broilerů na adici zeolitu do diety obsahující aflatoxin $\mathbf{B}_{1}$}

$\mathrm{V}$ pokusu bylo 29 klinicky zdravých brojlerů $\mathrm{z}$ provozních podmínek školního závodu, rozdělených do 4 skupin po 6-8 zviřatech: I. sk. - kontrolní, II. sk. adice $5 \%$ zeolitu, III. sk. - $5 \%$ zeolitu a $2,5 \mathrm{mg} \mathrm{AFB} \mathrm{AF}_{1} \cdot \mathrm{kg}^{-1}$ diety, IV. sk. jen $2,5 \mathrm{mg} \mathrm{AFB}_{1} \cdot \mathrm{kg}^{-1}$ diety. Zvírata byla zabíjena 5. a 12. dne pokusu. U IV. sk. došlo $\mathrm{k}$ výrazné heterofilii a lymfopenii, ve III. sk. byl tento posun mírnější. Ve všech histologických nálezech (včetně $\mathrm{I}$. sk.) byly zjištěny známky $\mathrm{v}$ minulosti proběhlého, mírného subklinického poškození jater (kulatobuněčné infiltráty v portobiliárních prostorech, histiocytové resorbční uzliky). $\mathrm{V}$ jaterních sinusoidech III.-IV. sk. byl prokázán značný výskyt eosinofilů, u II. sk. byl kolísavý. Přítomnost $A F B_{1} \mathrm{v}$ dietě (III. a IV. sk.) vyvolala akutní poškození jater charakteristické silnou aktivací hvězdicovitých (Kupfferových) buněk s největším výskytem po 12 dnech u IV. sk., kde byla rovněž prokázána nejvýraznější cholestasa ve žlučových kapilárách. Shodná cholestasa byla i u IV. sk. po 5 dnech a III. sk. po 12 dnech. Ložiskovité nálezy cholestasy byly nalczenny i u II. sk. (jen adice $5 \%$ zeolitu) po 12 dnech. Bylo zjištěno, že adice $5 \%$ zeolitu do diety, kontaminované aflatoxinem $\mathrm{B}_{1}$, netvoří spolehlivou ochranu před toxickým poškozením jaterní tkáně. $Z$ histologických nálezů II. sk. je patrné, že i samotný $5 \%$ doplněk zeolitu není pro organismus zcela neškodný.

\section{Гематологический и морфологический ответ у бройлеров на дачү $5 \%$ зеолита в диету с содержанием афпатоксина}

В ходе эксперимента исследовали содержащихся в учхозе 29 клинически здоровых бройлеров, разделенных в 4 группы, в каждой из которых насчитывалось 6 - 8 особей: I группа - контрольная, II группа - дача $5 \%$ зеолита, III группа - $5 \%$ зеолита и 2,5 мг афлатоксина В1.кr-1 диеты IV группа - только 2,5 мг афлатоксина В1.кг-1 диеты. Бройлеров умерщвляли на 5 и 12 сутки эксперимента. У IV группы наблюдались четко выраженные гетерофилия и лимфопения, В. III группе был данный сдвиг установлен несколько меньше. По гистологическим анализам всех групп (включая 1 группу) было установлено про- 
исшедшее в прошлом небольшое субклиническое повреждение печени (круглоклеточные инфильтраты в портобилиарном пространстве, гистиоцитарные резорбционные узелки). В синусоидах печени III-IV групп установили значительное число эозинофилов, у II группы данное количество колебалось. Присутствие афлатоксина В1 в диете (III) и IV группы) вызвало острое повреждение печени, характерное большой активностью звездчатых (купферовских) клеток с максимальным числом после 12 суток в IУ группе, в которой был установлен также самый выразительный холестаз в желчных капиллярах. Аналогичный холестаз наблюдали также у IV группы после 5 суток и III группы после 12 суток. Очаги холестаза были найдены также у II группы (дача только $5 \%$ зеолита) после 12 суток. Было установлено, что дача $5 \%$ зеолита в диету, контаминированную афлатоксином $\mathrm{B}_{1}$, не является надежной защитой от токсического повреждения ткани печени. На основе гистологических анализов II группы явно, что собственная $5 \%$ дача зеолита не является для организма совершенно безвредной.

\section{References}

BARTKO, P.-VRZGULA, L.: Zeolity vo výžive zvierat. 1. Základná charakteristika, výskyt a využitie pridaním do krmiva. Veterinářství, 31, 1981: 372-373.

CAMPBELL, J. R.-MAY, J. D.-HUFF, W. E.-DOERR, J. A.: Evaluation of immunity of young broiler chickens during simultaneous aflatoxicosis and ochratoxicosis. Poult. Sci., 61, 1982: 2 138-2 144

CARSON, M. S.-SMITH, T. K.: Role of bentonite in prevention of T-2 toxicosis in rats. J. Anim. Sci., 57, 1983: 1 498-1 503

CLARKE, R. N.-DOERR, J. A.-OTTINGER, M. A.: Relative importance of dietary aflatoxin and feed restriction on reproductive changes associated with aflatoxicosis in the maturing White Leghorn male. Poult. Sci., 65, 1986: 2 239-2 245

DAFALLA, R. - YAGI, A. I. - ADAM, S. E. I.: Experimental aflatoxicosis in hybro- type chicks: sequential changes in growth and serum constituents and histopathological changes. Vet. Hum. Toxicol., 29, 1987: 222-226

DVOR̂́K, M.: Schopnost bentonitu a přírodního zeolitu adsorbovat aflatoxin $\mathrm{z}$ tekutých prostředí. Vet. Med. (Praha), 34, 1989: 307-316

EDDS, G. T.-BORTELL, R. R.: Biological effects of aflatoxin in poultry. In: Aflatoxin and Aspergillus flavus in corn. Eds.: DIENER, U. L.-ASQUITH, R. L.-DICKENS, J. W., So. Coop. Ser. Bull., 279, Alabama University, 1983: 56-61

HAFEZ, A. M.-MEGALLA, S. E.-ABDEL-FATAH, H. M.-KAMEL, Y. Y.: Effects of aflatoxin on ovaries and testicles in mature domestic fowls. Assiut. Vet. Med. J., 11-12, 1979: $184-187$

CHU, F. S.: Mode of action of mycotoxins and related compounds. Adv. Appl. Microbiol., 22, 1977: $83-143$

JEFFERS, M.-LENGHAUS, C.: Granulocytopaenia and thrombocytopaenia in dairy cattlea suspected mycotoxicosis. Austr. Vet., J., 63, 1986: 262-263

KOČf, S. - KOČIOVÁ, E. - GERGELYIOVA, V.: Vplyv doplnkov zeolitov (klinoptilolitov) v krmivu na výkrmnost' brojlerov. Project report VÚCHSH, 1984, Ivanka pri Dunaji

MIŽIK, P. - HRUŠOVSKÝ, J. - TOKOŠOVA, M.: Vplyv prírodného zeolitu na vylučovanie a distribúciu rádiocézia u potkanov. Vet. Med. (Praha), 34, 1979: 467-474

MOHIUDDIN, S. M. - VIKRAM REDDY, M. - MADHAVA REDDY, M.-RAMAKVISHNA, K.: Studies on phagocytic activity and haematological changes in aflatoxicosis in poultry. Indian Vet. J., 63, 1986: 442-445

MOLLENHAUER, H. H.-CORRIER, D. E.-HUFF, E.-KUBENA, L. F.-HARVEY, R. B.-DROLESKEY, R. E.: Ultrastructure of hepatic and renal lesions in chickens fed aflatoxin. Am. J. Vet. Res., 50, 1989: 771-777

PEGRAM, R. A. - WYATT, R. D.-MARKS, H. L.: The relationship of certain blood parameters to aflatoxin resistance in Japanese quail. Poult. Sci., 65, 1986: 1652-1657 
POHUNKOVÁ, H.-SOVA, Z.-REISNEROVÁ, H.: Výsledky histologického a hematologického vyšetření slepic po perorálním podání $10 \mathrm{mg}$ ochratoxinu A. Sborník z mezinár. konf.: Mikroskopické houby a jejich toxické produkty jako faktor ovlivnující zdraví zvírat a člověka, Brno, 1989: B 44-46

SMITH, T. K.: Influence of dietary fiber, protein and zeolite on zearalenone toxicosis in rats. J. Sci., 50, 1980: 278-285

SOVA, Z. - REISNEROVÁ, H.-FUKAL, L.: Krevní obraz čínských křečků po perorální a intraperitoneální aplikaci $12,5 \mathrm{mg} \mathrm{AFL} . \mathrm{kg}^{-1}$. In: SOVA, Z.: Prưnik cizorodých látek do zvírat a jejich vliv na jaterni, reprodukčni a další funkce. Project report VII-4-9, VŠZ Praha, 1988: 75p.

SOVA, Z. - FUKAL, L.-SLÁMOVÁ, A. - TREFNÝ, D.-CIBULKA, J.: Studium vlivu adice zeolitu na metabolické testy a rezidua aflatoxinů $\mathrm{v}$ dietách o orgánech u brojlerů. Sborník VŠZ Praha, AF, ř. B, 48, 1988: 27-37

SOVA, Z.-FUKAL, L.-REISNEROVÁ, H.-VODIČKOVÁ, H.: Histopatologické nálezy na orgánech u nosnic po jednorázové aplikaci $10 \mathrm{mg}$ aflatoxinů. Sborník VŠZ Praha, AF, ř. B, 51, 1989: $31-46$

SOVA, Z. - REISNEROVA, H. -FUKAL, L.-POHUNKOVÁ, H. - VOŘfŠEK, J.: Rostoucí folikuly v ovariích nosnic po jednorázové aplikaci $10 \mathrm{mg}$ aflatoxinů. Biol. chem. Vet., 31, 1989: $259-267$

SOVA, Z.-POHUNKOVÁ, H.-SLÁMOVÁ, A.-REISNEROVÁ, H.-HAISL, K. et al.: Vliv plísňových toxinů na nosnice a brojlery $\mathrm{s}$ pokusem ovlivnit tvorbu reziduí zeolitem $\mathrm{v}$ dietě. Project report, VII-4-9, VŠZ Praha, 1989: 123 p.

STARK, A.: Mutagenicity and carcinogenicity of mycotoxins: DNA binding as a possible mode of action. Ann. Rev. Microbiol., 34, 1980: 235-262 